merce prohibited by and actionable under the Sherman Law."13 It is obvious that the two learned judges are reaching different results chiefly because they have different views as to what constitutes sound economic and social policy.

Especially worthy of note in the principal case is the scope of the privilege given the union. Not only may it call out its own members on strike if non-union men are employed or non-union materials used; it may also induce-by peaceful means, of course-workmen in other trades to leave a piece of work because non-union men are employed to install the materials coming from plaintiff's non-union shops. Whether one agrees with this or with the other results reached in the principal case will, naturally, depend upon one's views as to the desirability of allowing opportunity for the development of nationwide labor unions. The writer of the present comment is convinced that such a development is bound to take place, and that any attempt on the part of our courts to prevent its attainment by peaceful methods similar to those involved in the principal case will in the end prove ineffective. It is of course an open question whether without the aid of the legislature the courts will be able to solve the problem in a manner which, while giving ample opportunity for the development of collective bargaining, will properly protect the interests of all concerned.

W. W. C.

\title{
TESTAMENTARY CONTRACTS AND IRREVOCABLE WILLS
}

Confusion often results from the attempt of a property owner to purchase some valuable thing from another while retaining the benefit of the purchase price until his death, a case where the law seems to permit a person to have his cake and eat it too. Frequently the transaction takes the form of an agreement whereby the promisor, in return for some present consideration given by the promisee, agrees to give the latter by will all the property which he has at his death. Thus the promisor obtains the benefit of the contract while retaining that control over his property which is consistent with the power of testamentary disposition. The confusion results from the attempt to attach to the transaction the characteristics of both a will and a contract. These characteristics are, however, entirely distinct. A contract operates immediately to create a property interest in the promisee; while a will is revocable, or, more properly speaking, inoperative or ambulatory until the death of the testator, at which time it operates to create a property interest in the beneficiary. Or to give the more apposite terminology, the formation of a contract immediately vests in the promisee certain rights, privileges, powers and immunities; while a will does not have a like effect as regards the

${ }^{13} 244$ U. S. 473, 37, Sup. Ct. 720. 
beneficiary until the testator's death intervenes. ${ }^{1}$ And, as pointed out in Lazerence v. Prosser (I9I7, N. J. Ch.) IOI Atl. I040, the distinction need not be obscured by the fact that the same instrument which is the will also contains the written evidence of the contract. The agreement is not made subject to change by reason of being embodied in a document which is so subject. Where the will has been changed, the agreement may be enforced by specific performance or by fastening a trust upon the property left by the deceased.2

Hence, as some recent interesting decisions illustrate, contracts to devise or bequeath are quite uniformly upheld by the courts. In Lawrence $v$. Prosser, an agreement to make a will amply providing for the promisee was upheld through the medium of a trust, where the parties by making mutual wills subsequent to the contract had indicated what the extent of the provision was to be, though the promisor just before her death altered her will to the promisee's detriment. The same relief was accorded in Steinberger $v$. Young (I9I7, Cal.) I65 Pac. 432, where the deceased agreed with the plaintiff and the plaintiff's father to make the plaintiff her sole heir in consideration of the custody and control of the plaintiff and the rendition by her of obedience and services as a daughter. In Quirk v. Bank of Commerce $\mathcal{E}$ Trust Co. (I9I7, C. C. A. 6th) 244 Fed. 682, recovery in quantum meruit was allowed where an agreement to devise in consideration of the promisee's care of the promisor until death was unenforcible because of the statute of frauds. ${ }^{3}$ So an agreement in a partnership contract whereby one partner was to give each of the others promissory notes to be renewed from year to year and to be paid after his death was upheld in Eisenlohr's Estate (I9I7, Pa.) IO2 Atl. II7."

\footnotetext{
1 See Professor Hohfeld's analysis of fundamental legal conceptions (I9I3) 23 Yale LAw Journal 16, and (I9I7) 26 ibid. 7ro. The Comment in (I9I7) 27 Yale LAW JouRNal 263 on Hall v. Hall (I9I7) gI Conn. 5I4, suggests a situation under which the statement of the text may not be strictly accurate. Suppose A makes a will in B's favor, but is later improperly induced by C to change it. If $\mathrm{B}$ can obtain damages from $\mathrm{C}$, a point which as the Comment shows is by no means clear, then B does obtain immediately upon the execution of the will by A certain rights, etc. Those would be in the nature of "multital" or in rem rights, etc., while the promisee of a contract obtains not only the "multital" or in rem rights, etc., resulting from the rule that third persons must not interfere with the performance of contracts, but also valuable "paucital" or in personam rights, etc., against the promisee. For this terminology see Professor Hohfeld's article above mentioned in (I917) 26 YALE LAW JouRNAI 7 IO.

'Allen v. Bromberg (I906) I47 Ala. 317, 4I So. 771; Johnson v. Hubbell (I855) to N. J. Eq. 332.

As to the effect of the statute of frauds see p. 568 , infra.

-Distinguishing Beaumont's Estate (1906) 214 Pa. 445, 63 Atl. 1023, where a deed, in effect a mere power of attorney, containing a power of revocation and conveying no beneficial interest during the grantor's lifetime was held to be revoked by a will.
} 
The Court in Eisenlohr's Estate held that the mere fact that a writing was to become effective only after the death of a party was not sufficient to give it a testamentary character. It would seem immaterial, however, whether the contract had a testamentary character or not. Statutes governing the execution of wills do not apply to contracts, which operate to create present interests, and there is not the same need for formality in order to prevent imposition and fraud in a transaction participated in by two or more persons and involving an immediate change of position as there is in the solitary unilateral act of making a will, though both may look to the disposition of property after death. The immateriality of an intent to evade the wills acts where an otherwise binding contract is made was suggested some years ago by Mr. Justice Holmes in a decision upholding an agreement, without consideration but under seal, providing that the promisor's executors should make a payment of money six months after her death. ${ }^{5}$

In marked contrast to these cases, and to Eisenlohr's Estate in particular, is the utterly unjust and seemingly unjustifiable decision in Ferrara v. Russo. (I9I7, R. I.) I02 Atl. 86, where a contract between partners that in the event of the death of one the other should have the business and should pay the heirs of the deceased a stipulated sum was held testamentary in character and invalid since not executed as a will. ${ }^{\circ}$

Sargent v. Corey (I9I7, Cal. App.) I66 Pac. I02I, presents another angle of the question. Here the Court refused to declare a trust in favor of the plaintiffs upon an agreement looking to their adoption and providing that they should have all the promisor's property at his death, where subsequent to the making of the contract the promisor had married and left surviving him a wife and child to whom he willed his property, neither having knowledge of the contract until after his death. The Court based its decision upon the ground that it would be inequitable to enforce the contract against the widow and child. There may be some analogy to the statutes concerning a widow's property in her husband's estate and the statutes holding a will revoked by a subsequent marriage or birth of a child where the contingency is not provided for in the will. Yet the widow, under modern statutes,

${ }^{5}$ Krell v. Codman (I8gr) I54 Mass. 454, 28 N. E. 578. See also Bristol $v$. Warner (1848) r9 Conn. 7.

'The cases cited by the Court, Habergham v. Vincent (I793) 2 Ves. Jr. 204, 23I; Turner v. Scott (I866) 5 I Pa. 126; Frederick's Appeal (I866) 52 Pa. 338; Frew v. Clarke (1875) 80 Pa. 170, 178; and Cunningham v. Davis (I884) 62 Miss. 366 , are all cases where the transactions involved were entirely revocable until death. As contrary to Ferrara v. Russo, compare Crofut v. Layton (18g6) 68 Conn. 9r, 35 Atl. 783, holding valid an agreement between father and son, members of a partnership formed into a corporation, whereby each agreed to make a will leaving his shares of stock in the corporation to the other in order that the survivor should receive the other's stock. 
obtains an interest only in the property which her husband owns at death and it is only the ambulatory will which is revolked by marriage or birth of a child. It would seem that both widow and child must be considered more or less as volunteers and as not having claims superior to those acquired previously under a contract founded upon a valuable consideration. The decision would, therefore, seem doubtful unless, indeed, the court would go as far as did a New York court and say that such a contract was against public policy and void. ${ }^{7}$

The Court refused to allow an amendment to the complaint, showing that the promisor and a previous wife had made a joint will, not revoked before the latter's death, in the plaintiff's favor, without an allegation that the will was the result of a contract and was intended to be irrevocable. ${ }^{8}$ This seems clearly correct for joint or mutual wills do not differ in legal effect from other forms of wills, although additional results may flow from the existence of a contract between the makers that neither should revoke his will. And this leads us to our final problem, viz., whether a will itself can be made irrevorable by contract.

This question is answered in the affirmative in the curious case of Walker $v$. Yarbrough (I9I7, Ala.) 76 So. 39o. Here the probate court had probated an instrument which was in form a deed, reciting a present consideration and conveying all the property the grantor should own at her death to her husband, with the proviso that "this is to take effect only in case of my death prior to that of my husband." In accordance with the state practice permitting those interested who have not contested a will in the probate court to do so by bill in chancery, the beneficiaries under a will later in date filed their bill to set aside the probate of the earlier instrument, a copy of which they incorporated in their complaint. The majority of the court sustained the husband's demurrer to the bill on the ground that the earlier will being based on a valuable consideration was irrevocable. On rehearing they gave as an additional reason for the decision the fact that, as the probate of the later will would simply make necessary the enforcement of a trust of the property in the husband's favor either in a later action or by cross bill in this action, it would be a vain thing-"a display of legal gymnastics"-for a court of equity to act at all. ${ }^{\circ}$

\footnotetext{
${ }^{2}$ Gall v. Gall (1892, N. Y. Sup. Ct.) 64 Hun. 600, I9 N. Y. Supp. 332. The decision in the principal case followed Owens v. McNally (I8g6) Ir3 Cal. 444, 45 Pac. 7ro, where the court refused to enforce a contract whereby A was to care for B and have all B's property at the latter's death, B having subsequently married. This decision was referred to not unfavorably, though not followed, in Dillon v. Gray (IgI2) 87 Kan. 129, I23 Pac. 878. There is little direct authority. See Comment (I9I7) I6 Mich. L. Rev. 55.

${ }^{-}$Citing Learned's Estate (I909) I56 Cal. 309, I04 Pac. 3I5.

- See Comment (19I7) I6 MICH. L. Rev. 59. In Holcomb v. Gillet (I795, Conn.) 2 Root 448 , where a testator covenanted with A not to alter his will in
} 
A well known textwriter takes a somewhat similar position when he says that there seems to be no reason why a party may not agree not to make a will. ${ }^{10}$ He regards the agreement as affecting a destruction of testamentary power, making a subsequent will a nullity, or as an agreement to stand seised of the property to the promisee's use, or to hold it to his use, possession to commence at the promisor's death.11

In view of the promisor's power to dispose of his property during his lifetime, the promisee in such a transaction can have no "multital" or in rem relations in the property itself until after the promisor's death. When we say that a will is irrevocable all that we mean is that the fact of the promisor's death shall mark the transforming of the "paucital" or in personam relations against the promisor into the multital relations in the property itself rather than that this transformation should be marked by the specific performance of the contract or the enforcement of a trust under the direction of a court of equity, as is the case where there is a contract to devise or bequeath. ${ }^{12}$ And since the validity of a will must be tested before some court, what we are doing as a practical matter when we enforce a contract as an irrevocable will rather than as a contract to devise or bequeath is to throw the determination of the existence of the contract into the probate court. If we hold that a will may be made irrevocable by contract, then the court having jurisdiction of the probating of the will must decide whether or not such a contract exists in order to determine whether a later will should not be probated; while if we hold the will to be revocable but enforce the contract upon the property, then we leave it to a court of equity to ascertain the existence of the contract and to enable the promisee to make his relations in the property multital.13 Which course is to be taken is a question of policy. It

A's favor, and later because of the "false suggestions" of B did alter his will in B's favor, B was ordered by a court of equity to release the property to $A$.

${ }^{10}$ Gardner, Wills (2d ed.) 7o.

${ }^{11}$ Sed quaere. Would a subsequent will simply appointing an executor be a nullity? See note 15 infra, and compare Sumner v. Crane (I892) 155 Mass. $483,29 \mathrm{~N}$. E. II5I, holding that it is no objection to the probate of a will that the testator has made a valid contract to dispose of his property in a manner other than that provided in the will, or that the will offered for probate revokes a will drawn in accordance with the terms of the contract. The objection to the second suggestion is that the property upon which the agreement is to operate is entirely indefinite until the promisor's death.

${ }^{12}$ For definition of the terminology used see Professor Hohfeld, cit. note $r$, supra.

${ }^{13}$ If the instrument is irrevocable we ought not to apply to it the term "will," a term definitely appropriated to an important instrument with special legal characteristics, one of which is that it should not be irrevocable during the lifetime of the testator. Whether this is a conveyance, a power of appointment, or a contract enforced by refusing probate to a later instrument, it should not be called a will. It might even be doubted whether it should properiy be pro- 
would seem that the only argument for testing the matter in the probate court is that suggested in Walker v. Yarbrough, namely, the avoidance of litigation in a circle. On the other hand there are certain objections to such short cuts. The probate court ordinarily does not have the machinery to test such questions and the matter eventually comes to the higher court by a somewhat longer route. ${ }^{14}$ Then the later will may operate in part and thus necessitate the probating of both wills by the probate court with a resulting confusion which may be easily imagined.15 And it may be doubted if there is any real saving of litigation by placing the question in the hands of the probate court, for the real contest, which the situation is almost sure to cause, will occur in that court and that court only where the existence of the contract is to be determined. Hence the attitude of the minority judge in Walker $v$. Yarbrough that the contract should be left to a court of equity to enforce by appropriate action seems on the whole preferable.

This tendency of the majority in Walker $v$. Yarbrough to look for a short cut may have led them into a serious error, for they do not question the existence of the contract, though there is no evidence that the instrument had ever been delivered. In effect they hold that a contract is conclusively proven by an undelivered paper which. recites the giving of a consideration, though the giving of the consideration may actually have been planned to be concurrent with the delivery of the paper as is usually the case where a deed is delivered. Had it been necessary to bring an action upon the contract, the plaintiff in such an action would at least have had to prove his contract. C. E. C.

JURISDICTION OVER NON-RESIDENT CERTIFICATE HOLDERS OF DOMESTIC INSURANCE COMPANY

In the recent case of Hartford Life Ins. Co. v. Barber (IgI7) 38 Sup. Ct. 54, the United States Supreme Court reversed a decision of the Supreme Court of Missouri ${ }^{1}$ on the constitutional ground that the Missouri tribunal did not accord full faith and credit to a Connecticut judgment. ${ }^{2}$ A bare skeleton of the facts involved will serve our purpose for review. One Dresser, together with thirty others, holders of

bated, but, as the text indicates, if it is not probated, it is then practically assimilated to a contract to bequeath or devise.

"Compare the Connecticut rule that courts of probate cannot try title. Wilson v. Warner (I9II) 84 Conn. 560, 80 Atl. 718.

${ }^{15}$ Note Lazrence v. Prosser, supra, and Quick v. Bank of Commerce \& Trust Co., supra, in each of which the contract did not call for the entire estate. That a will is valid and entitled to probate even if it only appoints an executor see Prater v. Whittler (I88I) I6 S. C. 40, 46.

${ }^{2}$ (I916) 269 Mo. 2I, I87 S. W. 867.

$=$ U. S. Const. Art. IV, Sec. I. 